\title{
Pengembangan Media Pembelajaran Baca Tulis Permulaan Berlandaskan Karakteristik Siswa
}

\author{
Dwi Yulianti ${ }^{1}$ \\ Supriyadi $^{2}$ \\ Bambang Riadi ${ }^{3}$ \\ Munaris ${ }^{4}$
}

\begin{abstract}
The purpose of this study is to develop preliminary reading and writing instructional media for the first $\left(I^{s t}\right)$ grade elementary school students. The method used in this study is the Research and Development $(R \& D)$ approach. The results of the study were obtained from preliminary reading and writing instructional books the first level, level 2 and level 3. Content validation test results obtained mean rating 4.18, which means the instructional books content are very valid. Language validation test results obtained 4.24 which means that the language of learning instructional books are very good. Design validation results obtained 4.34, which means the instructional books design are very good. The effectiveness data shown that preliminary reading and writing instructional book has mean of 40.75 at $3 \leq R<4$, which means that the preliminary reading and writing instructional books categorized as very effective in facilitating students to learn how to read and how to write at the beginning.
\end{abstract}

Keyword: Preliminary reading-writing, instructional media, development method

Abstrak: Tujuan penelitian ini adalah mengembangkan media pembelajaran baca tulis permulaan untuk siswa kelas 1 Sekolah Dasar. Metode yang digunakan dalam penelitian ini adalah pendekatan Research and Development $(R \& D)$. Hasil penelitian diperoleh buku pembelajaran baca tulis permulaan level 1, level 2 dn level 3. Hasil uji validasi isi diperoleh rerata penilaian 4.18 , yang berarti isi buku pembelajaran sangat valid. Hasil Uji validasi kebahasaan diperoleh 4.24 yang berarti kebahasaan buku pembelajaran sangat baik. Hasil validasi desain diperoleh 4.34, yang berarti desain buku pembelajaran sangat baik. Data keefektifan menunjukkan buku pembelajaran baca tulis permulaan memiliki rerata 40.75 berada pada $3 \leq R<4$, ini berarti buku pembelajaran baca tulis permulaan dikategorikan sangat efektif untuk memfasilitasi siswa belajar baca tulis permulaan.

Kata kunci: baca-tulis permulaan, media pembelajaran, metode pengembangan

\section{PENDAHULUAN}

Pembelajaran baca dan tulis di sekolah dasar merupakan pembelajaran yang membutuhkan perhatian dari para pendidik. Hal ini disebabkan membaca adalah suatu proses interaksi memahami lambang bahasa melalui berbagai strategi untuk memahami makna dari yang tertulis, melibatkan aktivitas visual, berpikir, psikolinguistik, dan metakongnitif. Selain itu, membaca merupakan suatu proses penyandian kembali dan pembacaan sandi (Tarigan dalam Taufina, 2017:37). Adapun menulis adalah menurunkan atau melukiskan lambang-lambang grafik yang menggambarkan suatu bahasa yang dipahami oleh seseorang, sehingga orang lain dapat membaca lambang-lambang grafik tersebut kalau mereka memahami bahasa dan gambaran grafik itu (Tarigan dalam Taufina, 2017: 49).

Kemampuan membaca merupakan kunci keberhasilan (Adam, 1990; Honig, 1996; Snow, Burn dan Griffin, 1998 dalam Wood dan McLemore, 2001:1-8). Untuk itu pembelajaran membaca merupakan hal yang penting. Pentingnya membelajarkan baca permulaan menjadi perhatian diberbagai negara. Elliott dan Olliff (2008: 551-556) menyatakan pengembangan keterampilan baca dan tulis

\footnotetext{
${ }^{1}$ Dwi Yulianti, FKIP Unila, Jl Sumantri Brojonegoro 1 Gd Meneng, e-mail: safira_shodiq@yahoo.com

${ }^{2}$ Supriyadi, FKIP Unila, Jl Sumantri Brojonegoro 1 Gd Meneng.

${ }^{3}$ Bambang Riadi, FKIP Unila, Jl Sumantri Brojonegoro 1 Gd Meneng.

${ }^{4}$ Munaris, FKIP Unila, Jl Sumantri Brojonegoro 1 Gd Meneng.
} 
menjadi salah satu fokus untuk guru usia dini. Niemi, et.al (2011) memperhatikan pembelajaran baca dan berhitung kanak-kanak sampai kelas 1 sekolah dasar. Oleh sebab itu, pembelajaran baca dan tulis perlu dirancang semaksimal mungkin agar dapat memfasilitasi perolehan belajar baca dan tulis secara maksimal.

Membaca dan menulis dibedakan atas beberapa jenis keterampilan, antara lain keterampilan membaca dan menulis permulaan (Taufina, 2017: 37-50). Membaca dan menulis permulaan merupakan program pembelajaran yang diorientasikan pada kemampuan membaca dan menulis permulaan di sekolah dasar kelas awal (Rahmawati, 2017: 260). Ada banyak faktor yang memengaruhi perolehan belajar baca tulis permulaan. Salah satu faktor yang berperan penting adalah metode pembelajaran yang diterapkan guru.

Terdapat berbagai metode pembelajaran baca tingkat permulaan, yaitu 1) metode bunyi, 2) metode eja abjad, 3) metode kupas rangkai suku kata, 4) metode kata lembaga, 5) metode global dan 6) metode SAS (Taufina, 2017: 37), Jones, Clark dan Reutzel (2013: 81-89) menyajikan model Enhanced Alphabet Knowledge (EAK), Piasta dan Wagner (2010: 324-344) menyajikan model multilevel digunakan untuk membelajarkan baca permulaan pada anak-anak prasekolah. Adams \& Engelmann, Kameenui \& Carnine (dalam Kim \& Axelrod, 2005: 214-235) menggagas pembelajaran direct, sebab pembelajaran direct dapat mengatasi keterbatasan membaca dan berhitung siswa. Penelitian yang dilakukan Crowe., et al (2009: 187-214). Kamps., et al. (2008: 101-114), Stockard (2010: 1-16), menyatakan pembelajaran direct dapat membantu dan meningkatkan hasil belajar membaca. Siswa yang dibelajarkan dengan pembelajaran direct mampu mencapai skor tertinggi secara signifikan pada kinerja membaca dibandingkan dengan model yang lain. Menurut Morrison dan Premkumar (2014: 1-11) strategi pembelajaran direct antara lain menyediakan orientasi untuk self direct learning (SDL).

Berdasarkan berbagai macam pembelajaran baca yang ada disimpulkan, setiap metode memiliki keragaman pada fase-fase pembelajaran baca dan tulis tingkat permulaan. Dari keragaman fase-fase pembelajaran setiap metode, ada satu kesamaan dari seluruh metode, yaitu semua metode pembelajaran berupaya untuk memaksimalkan dan membantu pencapaian hasil belajar baca dan tulis tingkat permulaan secara efektif dan efisien. Dari keenam metode diatas, umumnya guru menggunakan metode SAS, bunyi dan eja abjad untuk membelajarkan baca tulis permulaan. Namun walaupun telah ada berbagai metode pembelajaran baca tulis permulaan, guru tetap merasa kesulitan jika membelajarkan baca tulis permulaan berbasis tema. Ini artinya guru membutuhkan bantuan untuk membelajarkan baca tulis permulaan berbasis tema.

Mengajar anak-anak untuk dapat membaca dan menulis merupakan kegiatan yang sulit (Wrigth., dkk, 1993 dalam Sukartiningsih, 2004: 52), apalagi untuk mengajar membaca menulis permulaan pada anak-anak usia kelas awal yang masih berada pada usia bermain dan belum memungkinkan mereka untuk dihadapkan pada situasi belajar yang serius (Sukartiningsih, 2004: 52). Hal senada menyatakan bahwa kegiatan membaca dan menulis merupakan kegiatan yang unik dan rumit sehingga seseorang 
tidak dapat melakukan tanpa mempelajarinya, terutama anak usia sekolah dasar yang belum mengenal huruf atau kata-kata (Saonah, 2018: 102).

Mendukung pernyataan bahwa pembelajaran baca tulis permulaan merupakan kegiatan yang membutuhkan perhatian serius dari pendidik, hasil observasi pada guru SDN di kabupaten Lampung Tengah, Lampung Selatan, Persawaran, Lampung Timur, Tanggamus. Hasil observasi menunjukkan guru merasa kesulitan untuk membelajarkan baca tulis permulaan dengan metode yang ada jika harus mengaitkan pembelajaran dengan tema-tema yang ada dalam kurikulum 2013. Hal ini mendukung hasil penelitian (Artapati dan Budiningsih, 2017: 185200) menyatakan hambatan guru melaksanakan kurikulum 2013 antara lain jumlah materi pembelajaran yang banyak namun tidak sesuai dengan alokasi waktu yang disediakan. Lebih lanjut hasil observasi mengungkapkan bahwa guru berpendapat, membelajarkan baca dan tulis sebaiknya belum dikaitkan dengan tema-tema. Pendapat tersebut didasari bahwa kemampuan membaca permulaan lebih diorientasikan pada kemampuan membaca tingkat dasar yakni kemampuan melafalkan lambang bunyi bahasa tulis (Rahmawati, 2017: 260). Oleh sebab itu pembelajaran baca tulis permulaan sebaiknya dipusatkan dahulu pada tujuan pembelajaran baca tulis permulaan, belum dikaitkan dengan tematema.

Pembelajaran baca tulis permulaan diorientasikan pada kemampuan membaca dan menulis tingkat dasar yakni kemampuan mengenal huruf dan kemampuan menulis mekanik (Halimah, 2014: 199). Kemampuan ini umumnya telah dibelajarkan di PAUD atau TK, namun rerata $20 \%$ siswa masuk kelas 1 SD di propinsi Lampung, tidak mengalami pendidikan di tingkat sebelumnya yaitu TK atau PAUD, sehingga mereka belum memiliki kemampuan baca tulis permulaan. Namun disisi lain $60 \%$ siswa telah memiliki kemampuan baca tulis permulaan sampai baca tulis huruf, suku kata, bahkan $20 \%$ telah memiliki kemampuan membunyikan dan menulis kata. Fakta ini menunjukkan keragaman kemampuan awal baca tulis permulaan siswa kelas 1 sekolah dasar.

Berdasarkan kajian terhadap (1) tujuan pembelajaran baca tulis permulaan, dan (2) kesulitan guru pada pembelajaran baca tulis permulaan jika pembelajaran baca tulis permulaan dijadikan bagian dari pembelajaran berbasis tema yang ada dalam kurikulum 2013. Untuk itu guru berpendapat, pembelajaran baca tulis tingkat permulaan di SD sebaiknya belum berbasis tematema, tapi baru mengenalkan simbol-simbol huruf. Lebih lanjut guru berpendapat, pembelajaran yang biasa diterapkan dengan metode yang ada, diakui mampu memfasilitasi siswa belajar baca tulis permulaan, tetapi sulit diterapkan jika pembelajaran baca tulis permulaan dijadikan bagian dari pembelajaran berbasis tema. Selanjutnya guru menjelaskan, jika pembelajaran baca tulis merupakan bagian pembelajaran berbasis tema-tema maka pembelajaran dan perhatian siswa menjadi terbagi-bagi untuk pembelajaran yang lain. Pada pembelajaran berbasis tema, pembelajaran baca tulis permulaan belum selesai, siswa telah dialihkan pada pembelajaran ilmu yang lain. Sebaiknya pembelajaran dilakukan dengan tahapan siswa terlebih dahulu mampu membaca 
dan menulis permulaan, lalu setelah itu dilanjutkan dengan pembelajaran ilmu yang lain menggunakan tema-tema. Tema-tema pembelajaran mulai digunakan setelah siswa dapat membaca dan menulis kata. Kelemahan pembelajaran baca tulis permulaan berbasis tema menyebabkan sistem pemrosesan informasi baca tulis permulaan dalam struktur kognitif siswa menjadi tidak maksimal. Ini artinya saat pembelajaran baca tulis permulaan, sistem yang terlibat dalam pemrosesan informasi perlu dipusatkan terlebih dahulu pada belajar baca tulis permulaan, setelah siswa memiliki kemampuan baca tulis permulaan kata, pembelajaran baru dikaitkan dengan tema-tema yang ada.

Beberapa kesulitan yang dialami guru pada pembelajaran baca tulis permulaan, yaitu kesulitan (1) pengenalan simbol. (2) penghapalan simbol, pada penghapalan simbol huruf siswa cenderung lupa dengan simbol-simbol yang telah dipelajari, ketika mereka belajar simbol huruf yang lain, (3) merangkai suku kata dan kemudian kata-kata. (4) mengelola waktu pembelajaran sebab pembelajaran dengan tema yang ada, beberapa KD pembelajaran mesti dicapai pada waktu yang telah ditetapkan. Sementara membelajarkan baca tulis permulaan membutuhkan waktu yang lebih lama untuk sampai pada tujuan pembelajaran baca tulis permulaan. (5) mengelola pembelajaran baca tulis berbasis tema untuk mencapai hasil belajar yang diharapkan.

Masalah kesulitan pembelajaran baca dan tulis tingkat permulaan pada siswa SD kelas rendah mengacu pada kurikulum 2013, tidak bisa dibiarkan begitu saja. Artinya perlu dicarikan solusi untuk mengatasi kesulitan guru membelajarkan baca tulis permulaan di SD kelas rendah. Salah satu solusi yang dapat dilakukan adalah dengan mengembangkan media pembelajaran baca tulis permulaan berbasis tematema yang ada dalam kurikulum 2013. Pertanyaannya, bagaimana media pembelajaran yang dapat memenuhi tujuan tersebut? Jawaban pertanyaan ini dapat dilihat dari kajian taksonomi variabel belajar, teori belajar dan karakteristik siswa.

Hasil belajar dipengaruhi variabel metode dan variabel kondisi (Degeng, 1989: 13). Mendukung pernyataan ini, hasil penelitian yang dilakukan oleh Dumford, Cogswll dan Miller (2016: 72-88) menunjukkan strategi pembelajaran terbukti menjadi bagian penting dari kesuksesan di kelas. Hal yang sama berlaku juga untuk pembelajaran baca permulaan. Penelitian yang dilakukan Karimhanlooei dan Seifiniya (2015: 769-777) menyatakan model pembelajaran dapat mempengaruhi tingkat pembelajaran bahasa kedua dan asing. Ulum (2015: 225-229) menyatakan penggunaan model pembelajaran kontekstual berpengaruh terhadap prestasi belajar bahasa Indonesia materi membaca permulaan anak berkesulitan belajar membaca. Ini artinya untuk meningkatkan hasil belajar perlu diperhatikan pemilihan dan penerapan model pembelajaran yang tepat. Makna model pembelajaran yang tepat adalah pembelajaran yang sesuai dengan kondisi yang ada.

Variabel kondisi mencakup antara lain ketersediaan media pembelajaran. Media pembelajaran baca tulis permulaan telah disediakan oleh pemerintah. Media pembelajaran tersebut berupa buku-buku pembelajaran untuk guru dan buku siswa berbasis pada tema-tema 
yang ada dalam kurikulum 2013. Buku guru dan buku siswa memiliki keunggulan dan kelemahan. Keunggulan media pembelajaran tersebut adalah telah memfasilitasi siswa belajar berbasis tema. Adapun salah satu kelemahan buku guru dan siswa untuk membelajarkan baca dan tulis permulaan adalah, tidak ada panduan yang dapat dijadikan sumber informasi, bagaimana cara pembelajaran baca tulis sesuai dengan karakteristik siswa dan tujuan pembelajaran baca tulis permulaan berbasis tema.

Karakteristik siswa SD kelas rendah adalah mereka masih berada pada kemampuan berpikir konkret. Sementara membaca dan menulis melibatkan simbol-simbol. Simbolsimbol merupakan sesuatu yang abstrak. Oleh sebab itu pembelajaran baca, tulis permulaan perlu mengaitkan pembelajaran baca dan tulis terutama pada pengenalan dengan hal-hal yang dekat dengan keseharian siswa. Hal-hal yang dikenal siswa biasanya yang terkait dengan keseharian mereka.

Keseharian siswa pada pembelajaran mengacu kurikulum 2013 tertuang dalam tematema pembelajaran. Ini artinya, solusi mengatasi kesulitan pembelajaran baca tulis permulaan mengacu pada kurikulum 2013, dapat diatasi dengan mengembangkan media pembelajaran baca tulis berbasis tema-tema yang telah ditetapkan. Media pembelajaran yang dimaksud sebaiknya dikembangkan dengan fase-fase pembelajaran yang memaksimalkan terjadinya pemrosesan informasi. Bagaimana fase-fase pembelajaran yang berpeluang untuk mencapai maksud membelajarkan baca tulis permulaan berbasis tema, sesuai dengan karakteristik siswa dan tujuan pembelajaran? Jawaban pertanyaan ini dapat ditinjau dari teori belajar. Ada banyak teori belajar antara lain teori behavioristik, konstruktivistik dan pemrosesan informasi.

Teori belajar behavioristik menyatakan hasil belajar sangat ditentukan dari bagaimana stimulus yang disajikan dari seorang guru sehingga menghasilkan respon dari siswa. Jika respon yang diharapkan dari siswa adalah siswa mampu menghapal, membedakan lalu dilanjutkan dengan mampu menulis dan kemudian membaca suku kata dan lalu kata, maka pembelajaran perlu memulainya dengan merancang stimulus untuk memfasilitasi tercapainya tujuan belajar yang dimaksudkan. Stimulus seperti apa yang berpeluang besar mencapai tujuan yang dimaksudkan untuk belajar baca tulis permulaan, jawaban atas pertanyaan ini dapat dilihat dari teori pemrosesan informasi.

Teori pemrosesan informasi menyatakan, semakin banyak indra dilibatkan saat menangkap informasi maka peluang informasi untuk diteruskan dalam memeori jangka pendek dan diteruskan dalam memori jangka panjang, selanjutnya untuk disimpan dalam memori jangka panjang, akan semakin besar. Ini artinya media pembelajaran baca tulis permulaan berbasis tema perlu dirancang untuk memfasilitasi siswa belajar baca tulis melalui sesuatu yang dilihat, didengar, dilakukan dan dirasakan.

Teori konstruktif senada dengan teori pemrosesan informasi tentang upaya memaksimalkan hasil belajar melalui pelibatan indra siswa secara maksimal. Teori belajar konstruktif menyatakan, jika belajar melalui mata maka siswa akan lupa, jika melibatkan mata dan telinga siswa akan paham, namun jika melibatkan seluruh indra siswa maka siswa akan memahami. 
Ini artinya media pembelajaran yang dibutuhkan siswa untuk belajar baca tulis tingkat permulaan adalah media yang memfasilitasi belajar baca melalui sesuatu yang dilihat, didengar, dilakukan dan dirasakan.

Kajian terhadap teori belajar untuk membelajarkan baca tulis permulaan, disimpulkan fase-fase pembelajaran untuk membelajarkan baca tulis tingkat permulaan berbasis tema, sesuai dengan karakteristik siswa dan tujuan pembelajaran baca tulis permulaan meliputi (1) pengenalan, (2) penghapalan, (3) penulisan dan (4) penguatan. Fase-fase pembelajaran tersebut memfasilitasi siswa untuk belajar mengenal, menghapal, membedakan huruf, menyebutkan, menuliskan, merangkai suku kata dan lalu kata sederhana.

Berdasarkan landasan teoritis, kebutuhan, karakteristik siswa dan landasan empiris terhadap belajar dan pembelajaran baca dan tulis dirumuskan masalah, (1) bagaimana media pembelajaran baca tulis tingkat permulaan untuk siswa SD kelas rendah mengacu pada kurikulum 2013 dan sesuai dengan tingkat perkembangan intelektual siswa, (2) bagaimana efektifitas pembelajaran baca tulis permulaan menggunakan media pembelajaran yang mengacu pada kurikulum 2013 dan sesuai dengan tingkat perkembangan intelektual siswa. Tujuan penelitian ini adalah menghasilkan media pembelajaran baca tulis permulaan yang sesuai dengan karakteristik siswa SD kelas rendah. Manfaat hasil penelitian adalah membantu guru memfasilitasi belajar baca tulis permulaan yang sesuai dengan karakteristik siswa kelas rendah.
Tujuan dan manfaat penelitian dicapai dengan mengembangkan media pembelajaran yang sesuai dengan kondisi yang ada. Pengembangan media pembelajaran diawali dengan menganalisis kondisi yang ada. Berdasarkan kondisi yang telah teridentifikasi tersebut, proses desain media pembelajaran dilakukan. Produk media yang diperoleh berupa buku pembelajaran yang didesain dengan teknik permainan dan mengangkat tema-tema muatan local dan konkret. Tahapan sajian buku hasil pengembangan yang memenuhi maksud ini terdiri dari (1) pengenalan, (2) penghapalan, (3) penulisan dan (4) penguatan.

\section{METODE PENELITIAN}

Penelitian ini merupakan penelitian pengembangan dengan prosedur pengembangan dibagi dalam lima tahapan. Produk yang dihasilkan pada penelitian ini adalah media pembelajaran baca tulis permulaan untuk SD kelas rendah. Tahapan penelitian sebagai berikut.

Tahap pertama, analisis kebutuhan siswa dan guru. Analisis kebutuhan dilakukan untuk mengetahui kesulitan dan masalah yang dihadapi guru dan siswa pada pembelajaran baca, tulis tingkat permulaan. Data kebutuhan siswa dan guru diperoleh dari lembar angket dan wawancara. Beradasarkan hasil wawancara dan isian angket diketahui guru membutuhkan media pembelajaran untuk membelajarkan baca tulis permulaan berbasis tema dan sesuai dengan karakteristik siswa SD kelas rendah.

Tahap kedua, Perumusan kisi-kisi kebutuhan berdasarkan kajian teoritis, guru dan siswa. Rumusan kisi-kisi kebutuhan adalah guru membutuhkan media pembelajaran yang dapat membantu guru mengatasi kesulitan 
pengenalan simbol, (2) menghapal simbol, (3) merangkai suku kata dan kemudian kata-kata, (4) mengelola waktu pembelajaran sebab pembelajaran dengan tema yang ada, dan (5) mengelola pembelajaran baca tulis berbasis tema untuk mencapai hasil belajar yang diharapkan.

Tahap ketiga, proses pengembang media pembelajaran. Tahap ini dilakukan dalam lima langkah proses pengembangan yaitu (1) mengidentifikasi dan menganalisis tujuan pembelajaran, (2) merumuskan tujuan pembelajaran, (3) identifikasi karakteristik siswa, (4) mengelola dan mengorganisir pembelajaran sesuai tema, (5) mengembangkan strategi pembelajaran baca tulis tingkat permulaan.

Tahap keempat penyusunan dan penulisan media pembelajaran Tahap ini merupakan tahap penyusunan dan penulisan media pembelajaran. media pembelajaran disusun mengacu pada bahan yang diperoleh dari langkah pengembangan (tahap 1, 2 dan 3 diatas).

Tahap kelima, validasi dan revisi, setelah dihasilkan media pembelajaran tahap berikutnya melalukan validasi. Validasi dilakukan untuk menghasilkan produk yang layak untuk digunakan. Validasi mencakup validasi ahli dan uji coba lapangan untuk mengetahui keefektifan pembelajaran baca tulis menggunakan media yang dikembangkan. Setelah kegiatan lima dilakukan, diperoleh produk yang telah memenuhi syarat dari aspek validasi ahli dan hasil uji coba lapangan. Hasil pengembangan menunjukkan produk layak untuk digunakan. Desain uji coba lapangan sebagai berikut.
Desain uji lapangan menggunakan satu kelompok pretes dan postes. Data dianalisis dengan menghitung peningkatan hasil belajar dari pretes dan postes. Berdasarkan data hasil peningkatan hasil belajar tersebut, guru diminta memberikan evaluasi terhadap peningkatan hasil belajar siswa, evaluasi dilakukan dengan mengisi instrumen keefektifan pembelajaran. Dengan kata lain, tingkat efektifitas diperoleh berdasarsarkan pendapat guru SD kelas 1 setelah mereka mengetahui peningkatakan hasil belajar siswa.

\section{Subyek Penelitian}

Penelitian dilakukan di propinsi Lampung dengan subyek penelitian terdiri dari subyek analisis kebutuhan dan subyek uji coba. Subyek penelitian adalah, 1) subyek analisis kebutuhan adalah siswa dan guru kelas satu SDN di propinsi Lampung, 2) subyek uji ahli pembelajaran adalah dosen rancangan pembelajaran minimal bergelar doctor, 3) subyek uji ahli isi adalag dosen pendidikan bahasa Indonesia dan dosen PGSD minimal bergelar doktor, 4) subyek uji perorangan adalah guru kelas 1 sekolah dasar, 5) subyek uji coba kelompok kecil adalah siswa sebanyak masing-masing 10 orang yang diambil dari empat SDN dari setiap kabupaten/kota, dan 6) subyek uji lapangan adalah siswa kelas I sekolah dasar dari setiap sampel kabupaten/kota. Untuk memperjelas penjelasan prosedur penelitian, disajikan gambar berikut ini.

\begin{tabular}{|c|c|c|}
\hline Pretes & Variabel Bebas & Postes \\
\hline $\mathrm{Y} 1$ & $\mathrm{X}$ & $\mathrm{Y} 2$ \\
\hline
\end{tabular}




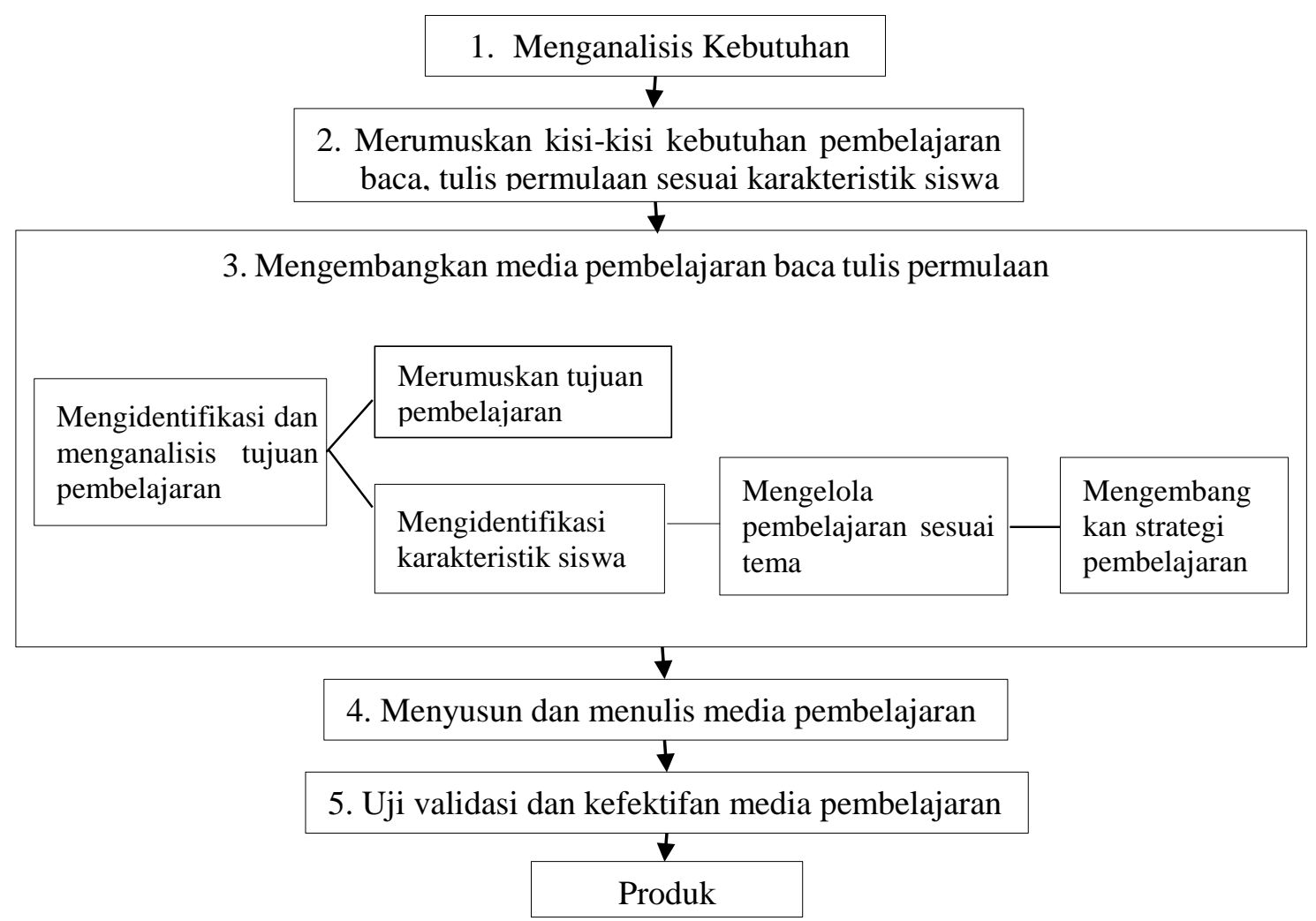

Gambar 1. Prosedur Pengembangan Media Pembelajaran

Penelitian ini menggunakan beberapa instrumen yaitu instrumen untuk (1) mengungkap data kebutuhan siswa dan guru, (2) validasi ahli isi, (3) validasi ahli desain, (4) validasi ahli kebahasaan, dan (5) instrument pretes, postes dan angket untuk mengetahui keefektifan media pembelajaran. Data kebutuhan diperoleh dari siswa dan guru SDN Lampung Timur, Lampung Selatan, Tanggamus, Pesawaran, Pringsewu, Lampung Tengah, kota Bandar Lampung dan Metro. Data validasi isi, diperoleh dari dosen PGSD bergelar doktor dan guru kelas 1 di SDN. Data validasi kebahasaan diperoleh dari dosen bahasa Indonesia bergelar doktor dan guru kelas 1 di SDN. Data validasi desain diperoleh dari dosen IP bergelar doktor dan guru kelas 1 di SDN. Data keefektifan diperoleh dari guru dan hasil pengamatan belajar siswa kelas 1 di SDN kabupaten/kota Pesawaran, Lampung Timur, Tanggamus, dan Pringsewu.

Metode yang digunakan untuk mengumpulkan data penelitian yaitu metode 1) check list, digunakan untuk mendapatkan data validasi isi, kebahasaan, desain media pembelajaran, keefektifan media pembelajaran, 2) wawancara digunakan untuk mendapatkan data kebutuhan siswa dan guru, 3) pengamatan digunakan untuk mendapatkan data keefektifan pembelajaran menggunakan media hasil pengembangan.

\section{HASIL PENELITIAN DAN PEMBAHASAN}

\section{Hasil penelitian}

Hasil wawancara dengan guru dan siswa diperoleh data kebutuhan guru dan siswa (1) guru 
membutuhkan cara pengenalan simbol yang tidak mudah dilupakan siswa, (2) cara mengingat simbol yang tidak mudah dilupakan, (3) cara membedakan simbol yang tidak mudah dilupakan, (4) cara membunyikan simbol yang tidak mudah dilupakan, (5) cara menulis simbol yang tidak mudah dilupakan. Ini berarti guru dan siswa membutuhkan (1) media yang dapat memfasilitasi siswa belajar dengan keberagaman kemampuan awal baca tulis permulaan, (2) guru membutuhkan media pembelajaran yang dapat mengarahkan guru untuk membelajarkan siswa sesuai dengan karakteristik anak yang masih senang bermain, (3) siswa membutuhkan media belajar yang sesuai dengan karakteristik mereka senang bermain.

Berdasarkan kebutuhan siswa dan guru dan landasan kajian teori-teori belajar dan karakteristik siswa, dikembangkan media pembelajaran yang sesuai dengan karakteristik siswa. Media pembelajaran yang dihasilkan berupa buku pembelajaran baca tulis tingkat permulaan hasil pengembangan memfasilitasi siswa belajar dengan fase-fase pembelajaran sebagai berikut.

\section{Pengenalan}

Pengenalan baca tulis tingkat permulaan melalui tema merupakan kegiatan yang memfasilitasi siswa untuk mengenal simbol dan bunyi huruf, suku kata dan kata melalui tematema yang ada. Pada tahap ini, media pembelajaran berisi pengarahkan pada guru guna mengenalkan huruf, suku kata atau kata yang membangun tema-tema. Kegiatan pengenalan dapat dilakukan dengan menggunakan berbagai teknik atau taktik pembelajaran, misalnya tema anggota tubuh mencakup pengenalan melalui nama-nama anggota tubuh pada siswa. Pengenalan dilakukan menggunakan teknik bernyanyi dilanjutkan dengan kegiatan menunjukkan anggota tubuh yang disebutkan dilagu, atau menggunakan kartu bergambar. Kemudian siswa diminta untuk menunjukkan dan menyebutkan nama-nama anggota tubuh mereka. Inti dari kegiatan pengenalan adalah mengenalkan siswa dengan lambang atau simbol dan bunyi dari huruf, suku kata atau kata.

\section{Pembunyian}

Penghapalan baca tulis tingkat permulaan merupakan fase pembelajaran yang memfasilitasi siswa untuk mampu mengingat dan membedakan simbol atau lambang dan bunyi huruf atau suku kata atau kata. Pada tahap ini, media pembelajaran berisi pengarahan pada guru untuk mengenalkan dan meminta siswa menghapal huruf, suku kata atau kata melalui nama anggota tubuh yang disebutkan kepada siswa. Penghapalan dapat dilakukan dengan berbagai teknik atau taktik yang sesuai dengan karakteristik siswa. Inti dari penghapalan adalah menguatkan memori siswa pada huruf, suku kata atau kata yang sedang dibelajarkan.

\section{Penulisan}

Pada tahap ini guru mengarahkan, melatih dan membimbing siswa menulis simbol dari huruf, suku kata atau kata. Teknik atau taktik penulisan dapat disesuai dengan karakteristik siswa dan kondisi yang ada. Salah satu teknik yang digunakan adalah dengan tahapan melatih siswa menulis huruf di udara, lalu di papan tulis. Secara bergilir seluruh siswa diminta menulis huruf dipapan tulis diiringi dengan menyebutkan huruf. Setelah seluruh siswa mendapat bimbingan dan kesempatan menulis dipapan tulis, tahap 
berikutnya adalah, guru melatih dan membimbing siswa menulis dilembar kegiatan peserta didik.

\section{Penguatan}

Penguatan merupakan kegiatan yang berguna untuk meningkatkan kemampuan memori menyimpan dan mengeluarkan kembali informasi yang telah disimpan didalam memori. Penguatan dapat dilakukan dengan berbagai teknik atau taktik, salah satunya adalah dengan pengulangan yang dilakukan berkali-kali. Kegiatan pengulangan dapat dimulai sejak penegenalan atau pembunyian, atau penulisan. Hal ini disesuaikan dengan kebutuhan siswa.

Produk pengembangan akan layak digunakan jika memiliki tingkat validitas isi, kebahasaan, desain dan memiliki keefektifan yang berada pada kategori baik. Untuk itu produk pengembangan berupa media pembelajaran baca tulis permulaan dilakukan berbagai uji validitas dan penilaian keefektifan. Hasil penelitian menunjukkan bahwa media pembelajaran baca tulis permulaan sesuai dengan karakteristik siswa memiliki validitas isi sangat valid, validitas desain sangat baik dan validitas kebahasaan sangat baik. Berikut data hasil validasi isi, kebahasaan, desain dan keefektifan media pembelajaran baca tulis permulaan sesuai dengan karakteristik siswa kelas $1 \mathrm{SD}$.

Tabel 1. Penilaian Validasi Isi Buku Pembelajaran Baca Tulis Permulaan

\begin{tabular}{|c|c|c|c|c|c|}
\hline No & $\begin{array}{l}\text { Indikator } \\
\text { Penilaian }\end{array}$ & & Butir Penilaian & $\begin{array}{c}\text { Rerata } \\
\text { Penilaian }\end{array}$ & Kategori \\
\hline \multirow[t]{3}{*}{1.} & Kesesuaian materi & 1) & Kelengkapan materi & 4.2 & Sangat valid \\
\hline & dengan tujuan & 2) & Keluasan Materi & 4.2 & Sangat valid \\
\hline & pembelajaran & 3) & Kedalaman materi & 4.2 & Sangat valid \\
\hline \multirow[t]{5}{*}{2.} & Keakuratan Materi & 4) & Keakuratan konsep dan definisi & 4.2 & Sangat valid \\
\hline & & 5) & Keakuratan data dan fakta & 4.2 & Sangat valid \\
\hline & & 6) & Keakuratan contoh dan kasus & 4.2 & Sangat valid \\
\hline & & 7) & $\begin{array}{l}\text { Keakuratan gambar, diagram, dan } \\
\text { ilustrasi }\end{array}$ & 4.2 & Sangat valid \\
\hline & & 8) & Keakuratan istilah-istilah & 4.2 & Sangat valid \\
\hline \multirow[t]{2}{*}{3.} & $\begin{array}{l}\text { Kemutakhiran } \\
\text { Materi }\end{array}$ & 9) & $\begin{array}{l}\text { Gambar, diagram dan ilustrasi } \\
\text { dalam kehidupan sehari-hari }\end{array}$ & 4.2 & Sangat valid \\
\hline & & 10) & $\begin{array}{l}\text { Menggunakan contoh dan kasus } \\
\text { yang terdapat dalam kehidupan } \\
\text { sehari-hari }\end{array}$ & 4.2 & Sangat valid \\
\hline
\end{tabular}

Berdasarkan data uji validasi isi diketahui, (1) kelengkapan materi, rerata penilaian yang diberikan validator adalah 4.2. Ini berarti pada bagian ini buku dikategorikan sangat valid.

(2) Keluasan materi, rerata penilaian yang diberikan validator adalah 4.2. Ini berarti pada bagian ini buku dikategorikan sangat valid. (3) Kedalaman materi, rerata penilaian yang diberikan validator adalah 4.2, ini berarti pada bagian ini buku dikategorikan sangat valid. (4) Konsep dan definisi yang digunakan, rerata penilaian yang diberikan validator adalah 4.6, ini berarti pada bagian ini buku dikategorikan sangat valid. (5) Data dan fakta yang digunakan, rerata penilaian yang diberikan validator adalah 4.2. Ini berarti pada bagian ini buku dikategorikan valid. 
(6) Contoh dan kasus yang digunakan, rerata penilaian yang diberikan validator adalah 4.2. Ini berarti pada bagian ini buku dikategorikan sangat valid. (7) Gambar, diagram dan ilustrasi yang digunakan, rerata penilaian yang diberikan validator adalah 4.2. Ini berarti pada bagian ini buku dikategorikan sangat valid. 8) Istilah yang digunakan, rerata penilaian yang diberikan validator adalah 4.2. Ini berarti pada bagian ini buku dikategorikan sangat valid. 9) Gambar, diagram dan ilustrasi yang digunakan, rerata penilaian yang diberikan validator adalah 4.2. Ini berarti pada bagian ini buku dikategorikan sangat valid. 10) Contoh dan kasus yang digunakan, rerata penilaian yang diberikan validator adalah
4.2. Ini berarti pada bagian ini buku dikategorikan sangat valid. Total rerata hasil validasi isi diperoleh 4.18 berada antara $4 \leq \mathrm{V}<5$, dengan kriteria sangat valid. Berdasarkan data ini disumpulkan bahwa buku pembelajaran baca tulis permulaan memiliki isi untuk membelajarkan baca tulis permulaan sesuai dengan tema dengan kategori sangat valid.

Data hasil validasi kebahasaan sebagai berikut. Validasi ahli bahasa dilakukan oleh validator guru SDN yang bergelar Magister Guru Sekolah Dasar, dan dosen pendidikan bahasa Indonesia bergelar doktor. Hasil validasi bahasa dan revisi yang telah dilakukan adalah sebagai berikut.

Tabel 2. Penilaian Validasi Kebahasaan Buku Pembelajaran Baca Tulis Permulaan

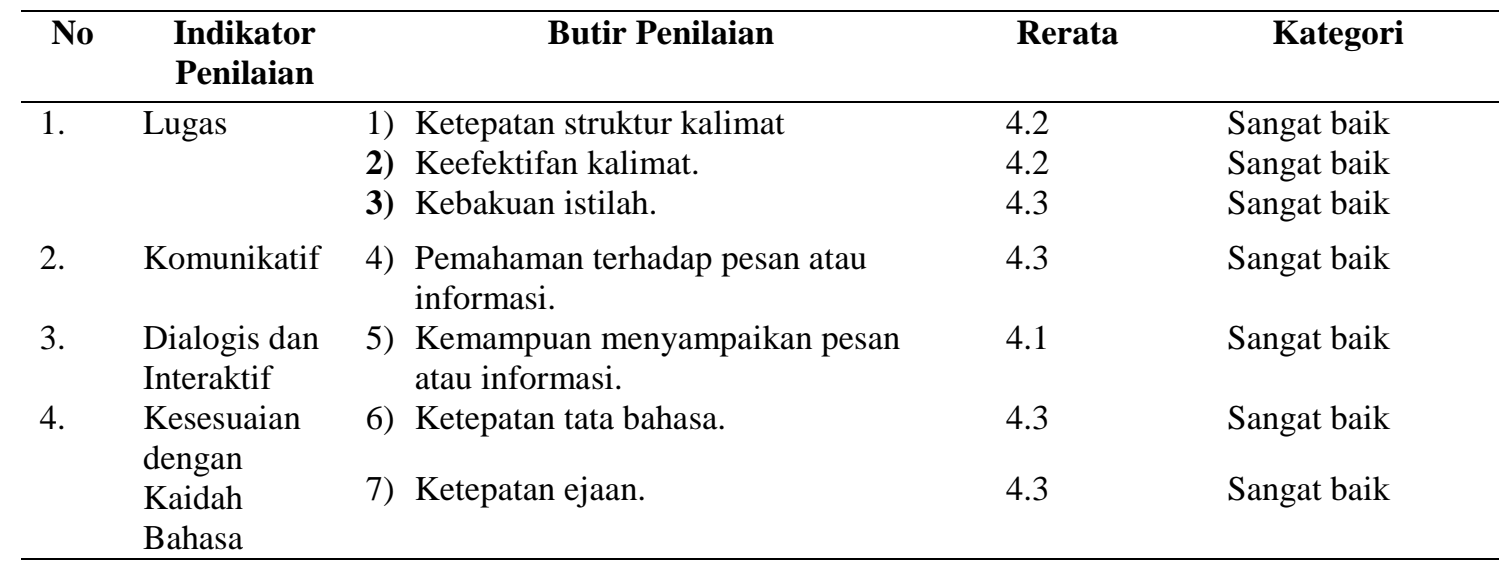

Berdasarkan data uji validasi kebahasaan buku pembelajaran level 1 diketahui, (1) ketepatan struktur kalimat, rerata penilaian yang diberikan validator adalah 4.2. Ini berarti pada bagian ini buku dikategorikan sangat baik. (2) Keefektifan kalimat, rerata penilaian yang diberikan validator adalah 4.2. Ini berarti pada bagian ini buku dikategorikan sangat baik. (3) Kebakuan istilah yang digunakan, rerata penilaian yang diberikan validator adalah 4.3. Ini berarti pada bagian ini buku dikategorikan sangat baik.
(4) Pemahaman terhadap pesan atau informasi, rerata penilaian yang diberikan validator adalah 4.3. Ini berarti pada bagian ini buku dikategorikan sangat baik. (5) Kemampuan menyampaikan pesan atau informasi, rerata penilaian yang diberikan validator adalah 4.1. Ini berarti pada bagian ini buku pembelajaran dikategorikan sangat baik. (6) Ketepatan tatabahasa, rerata penilaian yang diberikan validator adalah 4.2. Ini berarti pada bagian ini media pembelajaran dikategorikan sangat baik. (7) Ketepatan ejaan 
yang digunakan, rerata penilaian yang diberikan validator adalah 4.3. Ini berarti pada bagian ini media pembelajaran dikategorikan sangat baik. Total rerata penilaian validator bahasa untuk buku pembelajaran adalah 4.24, penilaian ini berada antara $4 \leq \mathrm{V}<5$. Ini artinya kebahasaan dari buku pembelajaran berada pada kategori sangat baik.
Buku pembelajaran baca tulis permulaan yang sesuai dengan karakteristik siswa, dilakukan validasi desain. Validator desain adalah guru SDN yang bergelar Magister Pendidikan Guru Sekolah Dasar dan dosen Teknologi pendidikan bergelar doktor. Hasil validasi desain diperoleh data sebagai berikut.

Tabel 3. Penilaian Validasi Desain Buku Pembelajaran Baca Tulis Permulaan

\begin{tabular}{|c|c|c|c|c|}
\hline No & $\begin{array}{l}\text { Indikator } \\
\text { Penilaian }\end{array}$ & Butir Penilaian & Rerata & Kategori \\
\hline 1. & Ukuran buku & $\begin{array}{l}\text { 1) Kesesuaian ukuran kertas dengan cover } \\
\text { dan materi isi. }\end{array}$ & 4.2 & Sangat baik \\
\hline \multirow[t]{23}{*}{2.} & \multirow[t]{9}{*}{$\begin{array}{l}\text { Desain } \\
\text { Sampul } \\
\text { (Cover) }\end{array}$} & $\begin{array}{l}\text { 2) Penampilan unsur tata letak pada sampul } \\
\text { muka, belakang dan punggung secara } \\
\text { harmonis memiliki irama dan kesatuan } \\
\text { serta konsisten. }\end{array}$ & 4.2 & Sangat baik \\
\hline & & $\begin{array}{l}\text { 3) Warna unsur tata letak harmonis } \\
\text { dan memperjelas fungsi }\end{array}$ & 4.2 & Sangat baik \\
\hline & & \multicolumn{3}{|c|}{ 4) Huruf yang digunakan menarik dan mudah dibaca: } \\
\hline & & $\begin{array}{l}\text { a. Ukuran huruf judul buku lebih } \\
\text { dominan dan proporsional } \\
\text { dibandingkan ukuran nama pengarang. }\end{array}$ & 4.6 & Sangat baik \\
\hline & & $\begin{array}{l}\text { b. Warna judul buku kontras dengan } \\
\text { warna latar belakang }\end{array}$ & 4.6 & Sangat baik \\
\hline & & $\begin{array}{l}\text { c. Tidak menggunakan terlalu banyak } \\
\text { kombinasi huruf }\end{array}$ & 4.2 & Sangat baik \\
\hline & & \multicolumn{3}{|l|}{ 5) Ilustrasi sampul buku } \\
\hline & & $\begin{array}{l}\text { a. Bentuk, warna, ukuran, proporsi } \\
\text { obyek sesuai realita. }\end{array}$ & 4.6 & Sangat baik \\
\hline & & $\begin{array}{l}\text { b. Menggambarkan isi/materi ajar dan } \\
\text { mengungkapkan karakter obyek. }\end{array}$ & 4.2 & Sangat baik \\
\hline & \multirow{14}{*}{$\begin{array}{l}\text { Desain Isi } \\
\text { buku }\end{array}$} & \multicolumn{3}{|l|}{ 6) Konsistensi tata letak } \\
\hline & & $\begin{array}{l}\text { a. Penempatan unsur tata letak konsisten } \\
\text { berdasarkan pola }\end{array}$ & 4.2 & Sangat baik \\
\hline & & b. Pemisahan antar paragrap jelas & 4.2 & Sangat baik \\
\hline & & \multicolumn{3}{|l|}{ 7) Unsur tata letak harmonis } \\
\hline & & a. Bidang cetak dan marjin proporsional & 4.6 & Sangat baik \\
\hline & & b. Spasi antar teks dan ilustrasi sesuai & 4.6 & Sangat baik \\
\hline & & \multicolumn{3}{|l|}{ 8) Unsur tata letak lengkap } \\
\hline & & $\begin{array}{l}\text { a. Judul kegiatan belajar, subjudul } \\
\text { kegiatan belajar, dan angka halaman. }\end{array}$ & 4.2 & Sangat baik \\
\hline & & b. Ilustrasi dan keterangan gambar & 4.2 & Sangat baik \\
\hline & & \multicolumn{3}{|l|}{ 9) Tata letak mempercepat halaman } \\
\hline & & $\begin{array}{l}\text { a. Penempatan hiasan/ilustrasi sebagai } \\
\text { latar belakang tidak mengganggu } \\
\text { judul, teks, angka halaman }\end{array}$ & 4.6 & Sangat baik \\
\hline & & $\begin{array}{l}\text { b. Penempatan judul, subjudul, ilustrasi, } \\
\text { dan keterangan gambar tidak } \\
\text { mengganggu pemahaman }\end{array}$ & 4.2 & Sangat baik \\
\hline & & \multicolumn{3}{|l|}{ 10) Tipografi isi buku sederhana } \\
\hline & & $\begin{array}{l}\text { a. Tidak menggunakan terlalu banyak } \\
\text { jenis huruf }\end{array}$ & 4.6 & Sangat baik \\
\hline
\end{tabular}




\begin{tabular}{|c|c|c|c|c|}
\hline No & $\begin{array}{l}\text { Indikator } \\
\text { Penilaian }\end{array}$ & Butir Penilaian & Rerata & Kategori \\
\hline & & $\begin{array}{l}\text { b. Penggunaan variasi huruf (bold, italic, } \\
\text { all capital, small capital) tidak } \\
\text { berlebihan }\end{array}$ & 4.6 & Sangat baik \\
\hline & & c. Lebar susunan teks normal & 4.6 & Sangat baik \\
\hline & & d. Spasi antar baris susunan teks normal & 4.6 & Sangat baik \\
\hline & & e. Spasi antar huruf normal & 4.6 & Sangat baik \\
\hline & & 11) Topografi isi buku memudahkan pemahar & & \\
\hline & & $\begin{array}{ll}\text { a. Jenjang judul-judul jelas, konsisten } \\
\text { dan proporsional }\end{array}$ & 4.2 & Sangat baik \\
\hline & & b. $\quad$ Tanda potongan kata & 4.2 & Sangat baik \\
\hline & & 12) Ilustrasi isi & & \\
\hline & & $\begin{array}{l}\text { a. Mampu mengungkap makna/arti dari } \\
\text { ojek }\end{array}$ & 4.2 & Sangat baik \\
\hline & & $\begin{array}{l}\text { b. Bentuk akurat dan proporsional } \\
\text { sesuai dengan kenyataan }\end{array}$ & 4.6 & Sangat baik \\
\hline & & c. Kreatif dan dinamis & 4.2 & Sangat baik \\
\hline \multicolumn{3}{|c|}{ Total Rerata Penilaian } & 4.34 & Sangat baik \\
\hline
\end{tabular}

Data hasil validasi desain menunjukkan bahwa pada aspek (1) kesesuaian ukuran kertas dengan cover dan materi isi, (2) penampilan unsur tata letak pada sampul muka, belakang dan punggung secara harmonis memiliki irama dan kesatuan serta konsisten, (3) warna unsur tata letak harmonis dan memperjelas fungsi menunjukkan pada masing-masing aspek, rerata penilaian 4.2 yang berarti (1) ukuran kertas dengan cover dan materi isi sangat sesuai, (2) penampilan unsur tata letak pada sampul muka, belakang dan punggung sangat harmonis memiliki irama dan kesatuan serta konsisten, (3) warna unsur tata letak harmonis dan memperjelas fungsi ini desain media pembelajaran dikategorikan sangat baik, (4) huruf yang digunakan menarik dan mudah dibaca, rerata penilaian 4.6 dan 4.2 yang berarti pada aspek ini kemenarikan dan kemudahan huruf dibaca sangat baik, (5) ilustrasi sampul buku, rerata penilaian 4.6 dan 4.2 yang berarti pada aspek ilustrasi sampul buku dikategorikan sangat baik, (6) konsistensi tata letak, rerata penilaian 4.2 yang berarti pada aspek konsistensi tata letak, buku pembelajaran dikategorikan sangat baik, (7) unsur tata letak harmonis rerata penilaian 4.2 yang berarti pada aspek unsur keharmonisan tata letak, buku pembelajaran dikategorikan memiliki unsur tata letak yang sangat harmonis, (8) kelengkapan tata letak, rerata penilaian 4.2 yang berarti pada aspek unsur tata letak, buku pembelajaran dikategorikan memiliki unsur tata letak yang sangat lengkap, (9) tata letak mempercepat halaman rerata penilaian 4.2 dan 4.6 yang berarti pada aspek unsur tata letak buku pembelajaran dikategorikan memiliki unsur tata letak yang sangat mempercepat halaman. Hasil validasi desain buku pembelajaran baca tulis permulaan diperoleh total rerata 4.34 , ini menunjukkan buku pembelajaran baca tulis permulaan telah memiliki desain dengan kategori sangat valid, dengan kata lain buku pembelajaran baca tulis permulaan memiliki desain yang sangat baik.

Untuk mengetahui keefektifan pembelajaran menggunakan buku pembelajaran hasil pengembangan, dilakukan pengamatan. Berdasarkan hasil pengamatan diperoleh data sebagai berikut. 
Tabel 4. Data Keefektifan Buku Pembelajaran Baca Tulis Permulaan

\begin{tabular}{|c|c|c|c|}
\hline No & Aspek yang Diamati & Rerata & Kategori \\
\hline 1. & $\begin{array}{l}\text { Media pembelajaran } \\
\text { membangkitkan } \\
\text { semangat siswa } \\
\text { untuk belajar }\end{array}$ & 4.2 & $\begin{array}{l}\text { Sangat } \\
\text { baik }\end{array}$ \\
\hline 2. & $\begin{array}{l}\text { Media pembelajaran } \\
\text { mengarahkan siswa } \\
\text { secara bertahap } \\
\text { untuk belajar baca } \\
\text { tulis permulaan }\end{array}$ & 4.6 & $\begin{array}{l}\text { Sangat } \\
\text { baik }\end{array}$ \\
\hline 3. & $\begin{array}{l}\text { Media pembelajaran } \\
\text { memfasilitasi siswa } \\
\text { untuk mampu belajar } \\
\text { mandiri }\end{array}$ & 4.6 & $\begin{array}{l}\text { Sangat } \\
\text { baik }\end{array}$ \\
\hline 4. & $\begin{array}{l}\text { Media pembelajaran } \\
\text { memfasilitasi siswa } \\
\text { untuk memiliki } \\
\text { keingintahuan yang } \\
\text { tinggi sehingga } \\
\text { senang untuk belajar } \\
\text { baca tulis yang } \\
\text { sedang diabelajarkan } \\
\text { guru }\end{array}$ & 4.2 & $\begin{array}{l}\text { Sangat } \\
\text { baik }\end{array}$ \\
\hline 5. & $\begin{array}{l}\text { Media pembelajaran } \\
\text { mengaktifkan siswa } \\
\text { untuk belajar }\end{array}$ & 4.2 & $\begin{array}{l}\text { Sangat } \\
\text { baik }\end{array}$ \\
\hline 6. & $\begin{array}{l}\text { Media pembelajaran } \\
\text { memfasilitasi siswa } \\
\text { menulis huruf atau } \\
\text { suku kata atau kata } \\
\text { dengan benar }\end{array}$ & 3.6 & Baik \\
\hline 7. & $\begin{array}{l}\text { Media pembelajaran } \\
\text { memfasilitasi siswa } \\
\text { membunyikan huruf } \\
\text { atau suku kata atau } \\
\text { kata dengan benar }\end{array}$ & 3.6 & Baik \\
\hline 8. & $\begin{array}{l}\text { Media pembelajaran } \\
\text { memfasilitasi siswa } \\
\text { membedakan huruf } \\
\text { atau suku kata atau } \\
\text { kata }\end{array}$ & 3.6 & Baik \\
\hline & Rerata & 40.75 & $\begin{array}{l}\text { Sangat } \\
\text { baik }\end{array}$ \\
\hline
\end{tabular}

Data pada table 4 menunjukkan buku pembelajaran baca tulis permulaan memiliki rerata 40.75 berada pada $3 \leq \mathrm{R}<4$, ini berarti buku pembelajaran baca tulis permulaan dikategorikan sangat efektif untuk memfasilitasi siswa belajar baca tulis permulaan.

\section{Pembahasan}

Produk buku pembelajaran baca tulis permulaan sesuai dengan karakteristik siswa memiliki tingkat validitas isi, kebahasaan dan desain dengan kategori yang sangat baik. Ini menunjukkan buku pembelajaran layak digunakan sebagai salah satu suplemen pembelajaran baca tulis permulaan di SD kelas rendah. Produk pengembangan akan layak digunakan jika telah memiliki antara lain validitas isi, kebahasaan dan desain dengan kategori baik.

Produk buku pembelajaran hasil pengembangan memiliki keefektifan yang berada pada kategori sangat efektif, hal ini disebabkan buku pembelajaran disusun berdasarkan kebutuhan siswa dan guru. Hasil pengembangan yang kembangkan berdasarkan kebutuhan memiliki kegunaan yang tinggi. Hasil penelitian (Haryanto, 2009: 157), menunjukkan bahwa penggunaan media pembelajaran dapat meningkatkan hasil belajar baca tulis permulaan. Penelitian dilakukan berdasarkan kebutuhan siswa dan guru terhadap pembelajaran baca tulis permulaan.

Salah satu kebutuhan siswa kelas rendah untuk mampu membangun kemampuan dan keterampilan baca tulis permulaan adalah media yang mampu memfasilitasi belajar sesuai dengan karakteristik mereka yang masih senang bermain. Model hasil pengembangan penelitian ini, memfasilitasi siswa belajar baca tulis permulaan dengan bermain. Permainan ada pada setiap teknik atau taktik di setiap tahapan model pembelajaran. Salah satu teknik yang digunakan adalah kartu yang berisi simbol huruf dilengkapi dengan bergambar. Kartu digunakan dengan teknik bermain tebak kata. Penggunaan kartu 
dengan teknik bermain meningkatkan keefektifan model pembelajaran hasil pengembangan. Hasil penelitian ini mendukung hasil penelitian sebelumnya (Saonah, 2018:107) menyatakan media gambar dapat meningkatkan hasil belajar baca tulis permulaan, (Patty, 2015: 172-178) menyatakan 90,5\% siswa mencapai KKM pada pembelajaran menulis permulaan menggunakan model induktif kata bergambar, (Rumidjan., dkk, 2017: 62-68) menyatakan 94\% siswa merasa senang dan mudah belajar keterampilan membaca permulaan menggunakan media kartu kata.

Fakta hasil obeservasi di berbagai SDN di Propinsi Lampung menunjukkan masih ada 30\% siswa kelas 1 SD belum mengalami pendidikan sebelumnya yaitu PAUD atau TK. Keberagaman kemampuan awal siswa diatasi dengan mengembangkan media pembelajaran baca tulis yang dibagi dalam tiga level, yaitu level huruf, suku kata dan kata. Pengembangan pembelajaran dengan tiga level ini memberi kesempatan guru untuk memilih media pembelajaran yang sesuai dengan karakteristik kemampuan awal siswanya. Guru dapat memulai pembelajaran baca tulis sesuai dengan kemampuan awal siswanya. Untuk siswa yang belum pernah menempuh pendidikan sebelumnya yaitu TK atau PAUD, maka guru dapat memulai pembelajaran dengan media tingkat huruf. Jika siswa telah mengenal huruf, maka guru dapat memulai pembelajaran dengan pembelajaran tingkat suku kata, dan jika siswa telah memiliki kemampuan baca tulis permulaan pada kompetensi kemampuan membunyikan suku kata, maka guru dapat memulai pembelajaran dengan tingkat kata. Dengan demikian media pembelajaran hasil pengembangan sangat membantu guru dalam membelajarakan baca tulis permulaan dengan karakteristik kemampuan awal baca tulis yang beragam.

Media hasil pengembangan sangat dinamis digunakan sesuai dengan kemampuan awal siswa, sehingga memiliki keefektifan yang sangat tinggi. Hasil penelitian ini mendukung 1) hasil penelitian (Susilo, 2016: 167-168), menunjukkan pengetahuan awal tinggi dan rendah berpengaruh lebih baik terhadap hasil belajar membaca pemahaman dengan metode pembelajaran problem based learning dibandingkan dengan metode directed thinking activities, 2) pernyataan (Dahar, 1988: 201) Piaget dan para konstruktivis pada umumnya berpendapat bahwa dalam membelajarkan siswa seharusnya perlu memperhatikan pengetahuan yang telah diperoleh sebelumnya. Mengacu pendapat ini disimpulkan bahwa hal-hal konkret yang memungkinkan untuk membelajarkan kemampuan baca, tulis adalah pengetahuan yang telah diperoleh siswa sebelumnya. Pengetahuan yang telah diperoleh siswa kelas rendah sebelumnya adalah pengetahuan yang dialami siswa sehari-hari, ini artinya media pembelajaran baca tulis perlu dirancang berdasarkan pada tematema tentang kegiatan siswa sehari-hari, dan memfasilitasi keragaman kemampuan awal baca tulis permulaan. Selain itu (Degeng, 1989: 145) menyatakan makin dekat kesamaan karakteristik si-belajar dengan media yang dipakai, makin tinggi pengaruh motivasional yang ditimbulkan oleh media itu.

Media pembelajaran dikembangkan berdasarkan kebutuhan siswa dan guru, selain itu pengembangan dilandasi kajian teoritis pada teori belajar dan karakteristik siswa. Berdasarkan kajian teoritis, media pembelajaran 
dikembangkan dengan tiga level pembelajaran, yaitu level pembelajaran huruf, suku kata dan kata. ketiga level pembelajaran ini diterapkan secara berurutan dimulai dari pembelajaran huruf, dilanjutkan suku kata dan terakhir kata. Setiap level pembelajaran terdiri dari tahapan pembelajaran yang dilakukan secara berurutan. Setiap level terdiri dari tahapan pengenalan dilanjutkan pembunyian penulisan dan berakhir dengan penguatan. Keempat tahapan dilakukan secara berurutan. Perancangan media pembelajaran pada masing-masing level menjadi empat tahapan, memiliki keunggulan. Keunggulan itu sesuai dengan teori pemrosesan informasi, teori belajar behavioristik dan teori lupa.

Untuk membelajarkan baca tulis permulaan, hal lain yang perlu mendapat perhatian utama adalah teori lupa dan kejenuhan belajar. Hal ini perlu mendapat perhatian utama, sebab belajar membaca, menulis dan berhitung mencakup huruf dengan jumlah 26 huruf. Selain itu untuk memiliki kemampuan membaca dan menulis siswa perlu memiliki kemampuan membaca dan menulis kata yang dibangun oleh rangkaian suku kata dan suku kata dibangun dari huruf-huruf. Ada peluang besar terjadi lupa terhadap huruf yang telah dipelajari sebelumnya ketika siswa belajar huruf berikutnya. Selain ada peluang terjadi lupa, ada juga peluang besar terjadi kejenuhan siswa belajar membaca dan menulis. Seorang siswa yang sedang dalam keadaan jenuh, sistem akalnya tidak dapat bekerja sebagaimana yang diharapkan dalam memproses item-item informasi sehingga kemajuan belajarnya seakan-akan berjalan ditempat (Syah, 2014). Masalah lupa dan kejenuhan banyak dialami siswa SD kelas 1 ketika belajar baca tulis permulaan. Masalah ini diatasi dengan mengembangkan media pembelajaran yang memfasilitasi belajar dengan memaksimalkan bekerjanya sistem pemrosesan informasi siswa. Media pembelajaran dikembangkan dengan tiga level dan setiap level atau tingkatan dirancang dengan empat tahapan pembelajaran yaitu pengenalan, pembunyian, penulisan dan penguatan. Tahapan ini mampu menguatkan sistem memori untuk menyimpan dan mengeluarkan kembali huruf, suku kata dan kata yang telah dipelajari.

Teori belajar behavioristik menyatakan hasil belasjar sangat ditentukan dari bagaimana stimulus yang disajikan dari seorang guru sehingga menghasilkan respon dari siswa. Jika respon yang diharapkan dari siswa adalah siswa mampu menghapal, membedakan lalu dilanjutkan dengan mampu menulis dan kemudian membaca huruf, suku kata dan lalu kata, maka pembelajaran perlu memulainya dengan merancang stimulus untuk memfasilitasi tercapainya tujuan belajar yang dimaksudkan. Media pembelajaran hasil penelitian ini merancang stimuli dengan menyajikan benda-benda atau kejadian yang lekat dengan keseharian siswa, menarik dan dapat dilihat.

Teori pemrosesan informasi menyatakan, semakin banyak indra dilibatkan dalam proses belajar, maka peluang semakin untuhnya informasi tertangkap oleh indra semakin besar. Jika informasi yang tertangkap indra semakin utuh, maka peluang informasi untuk diteruskan kedalam memori jangka panjang semakin besar. Jika indera yang dilibatkan dalam belajar semakin banyak, maka peluang kemudahan untuk 
memanggil informasi yang telah disimpan dalam memori jangka panjang semakin besar. Hal ini disebabkan jaringan pengaitan informasi baru dalam struktur kognitif siswa semakin banyak, karena informasi yang diproses dalam jaringan pemrosesan informasi memaksimalkan penggunaan seluruh indera siswa. Ini artinya model pembelajaran yang menekankan teknik permainan, mengangkat tema-tema muatan local dan bersifat konkret, perlu dikembangkan dengan memperhatikan tahapan pemrosesan informasi.

Media pembelajaran hasil penelitian ini dikembangkan dengan memaksimalkan pelibatan indra siswa untuk belajar. Pemaksimalan itu tercermin dalam tahapan peebelajaran pada masing-masing tingkatan yaitu tahapan pengenalan, pembunyian, penulisan dan penguatan. Masing-masing tahap pembelajaran memfasilitasi siswa belajar menggunakan gambar. penggunaan gambar memiliki keunggulan dapat meningkatkan keefektifan pembelajaran baca tulis permulaan. hal ini didukung hasil penelitian (Haryanto, 2009: 157; Saonah, 2018: 107), pembelajaran menggunakan media gambar dapat meningkatkan kemampuan baca tulis permulaan siswa.

\section{KESIMPULAN}

Ada tiga kesimpulan penelitian sebagai berikut.

Pertama, buku pembelajaran yang sesuai dengan kebutuhan siswa dan guru adalah buku pembelajaran yang terdiri dari tiga tingkatan atau level. Setiap level terdiri dari empat tahapan yaitu tahapan pengenalan, pembunyian, penulisan dan penguatan.
Kedua, buku pembelajaran dikembangkan berbasis tema yang sesuai dengan tema yang ada dalam kurikulum 2013. Untuk membantu guru membelajarkan baca tulis permulaan berbasis tema, media pembelajaran berisi panduan pembelajaran untuk guru. Panduan diberikan pada setiap tahapan dari setiap tingkat pembelajaran baca tulis permulaan.

Ketiga, buku pembelajaran hasil pengembangan memiliki keefektifan yang sangat tinggi, hal ini disebabkan media dikembangkan berdasarkan (1) kebutuhan siswa dan guru, (2) memperhatikan berbagai teori belajar, peluang terjadinya kejenuhan dan lupa, dan (3) memperhatikan karakteristik siswa

\section{DAFTAR PUSTAKA}

Artapati, Lalu Wirya., Budiningsi, Asri. Pelaksanaan Kurikulum 2013 di SD Negeri Serayu Yogyakarta. Jurnal Inovasi Teknologi Pendidikan Vol. 4, Nomor: 2, 2017, P-ISSN 2407-0963, eISSN 2460-7177, hal. 185-200. Diakses 3 Agustus 2018.

Crowe, E. C., Connor, C. M., \& Petscher, Y. 2009. Examining the Core: Relations among Reading Curricula, Poverty, and First through Third Grade Reading Achievement. Journal of School Psychology, 47: 187-214.

Dahar, R.W. 1988. Teori-Teori Belajar. Jakarta: Departemen Pendidikan dan Kebudayaan Dirjen Pendidikan Tinggi P2LPTK.

Degeng, I.N.S. 1989. Ilmu Pengajaran: Taksonomi Variabel. Jakarta: Departemen Pendidikan dan Kebudayaan Dirjen Pendidikan Tinggi.

Dumford, Amber D., Cogswell, Cindy A., Miller, Angie L. 2016. The Who, What, and Where of Learning Strategies. The Journal Devoted to Teaching Excellence. 16 (1): 72-88. 
Elliott, Elizabeth M., Olliff, Charleen B. 2008. Developmentally Appropriate Emergent Literacy Activities for Young Children: Adapting the Early Literacy and Learning Model. Early Childhood Education Journal. 35 (6): 551-556.

Halimah, Andi. Metode Pembelajaran Membaca dan Menulis di SD/MI. Jurnal Pendidikan Dasar Islam Vol. 1 nomor: 2, Desember 2014, hal. 190-200. (online) www.jurnal baca tulis permulaan. Diakses 22 Juli 2018.

Haryanto. Upaya Meningkatkan Kemampuan Membaca dan Menulis Permulaan dengan Media Gambar. https://digilib.uns.ac.id/upaya meningkatkan, hal 1-164. Diakses 22 Juli 2018.

Jones, Cindy D., Clark, Sarah K., Reutzel, D. Ray. 2013. Enhancing Alphabet Knowledge Instruction: Research Implications and Practical Strategies for Early Childhood Educators. Early Childhood Education Journal. 41:81-89

Kamps, D., Abbott, M., Greenwood, C., Wills, H., Veerkamp, M., \& Kaufman, J. 2008. Effects of Small Group Reading Instruction and Curriculum Differences for Students Most at Risk in Kindergarten:Two-year results for secondary and tertiary level interventions. Journal of Learning Disabilities, 41(2), 101-114.

Karimkhanlooei, Giti., Seifiniya, Hadis. 2015. Teaching Alphabet, Reading and Writing for Kids between 3-6 Years Old as a Second Lenguage. Procedia Social and Behavioral Sciences. 192: 769-777.

Kim, T. \& Axelrod, S. 2005. Direct Instruction: An Educators' Guide and a Plea for Action. The Behavior Analyst Today, 3(2), 214-235.

Morrison, Dirk and Premkumar, Kalyani. 2014. Practical Strategies to Promote SelfDirected.Learning in The Medical Curriculum. International Journal of Self-Directed Learning. 11(1): 1-11

Niemi, Pekka., Nurmi, Jari-Erik., Lyyra, AnnaLiisa. 2011. Task Avoidance, Number Skills and Parental Learning
Difficulties as Predictors of Poor Response to Instruction Journal of Learning Disabilities. 44 (5).

Patty, Rachmawaty. Pengembangan Model Induktif Bergambar pada Pembelajaran Menulis Permulaan. Jurnal Sekolah Dasar Tahun 24, nomor: 2, November 2015, p-ISSN 0854-8285, e-ISSN 2581-1983, hal. 172-179. Diakses 3 Agustus 2018.

Piasta, Shayne B., Wagner, Richard K. 2010. Learning Letter Names and Sound: Effects of Instruction, Letter Type, and Phonological Processing Skill. Journal Exp Child Psychol. 105(4): 324-344.

Rahmawati. Strategi Pembelajaran Membaca dan Menulis melalui Kata Bergambar. Jurnal SAP Vol. 1, nomor: 3, April 2017, p-ISSN 2527-967x, e.ISSN 2549-2845, hal. 259-270. (online) www.jurnal baca tulis permulaan. Diakses 28 Juli 2018.

Rumidjan., Sumanto., Badawi, A. Pengembangan Media Kartu Kata untuk Melatih Keterampilan Membaca Permulaan pada Siswa Kelas 1 SD. Jurnal Sekolah Dasar (Kajian Teori dan Praktik Pendidikan) Tahun 26, nomor: 1, Mei 2017, p-ISSN 0854-8285, e-ISSN 2581-1983, hal. 62-68. (online). Diakses 3 Agustus 2018.

Saonah, Siti. Meningkatkan Kemampuan Membaca dan Menulis Permulaan dengan Media Gambar Di Kelas 1 SDN 222 Pasir Pogor. Jurnal Elementaria Edukasia Vol. 1, nomor: 1, 2018. ISSN: 2615-4625, hal. 101-107. (online) www.jurnal baca tulis permulaan. Diakses 26 Juli 2018.

Sukartiningsih, Wahyu. 2004. Peningkatan Kualitas Pembelajaran Membaca dan Menulis Permulaan di Kelas 1 Sekolah Dasar melalui Media Kata Bergambar. Jurnal Pendidikan Dasar. Vol. 5, nomor: 1, 2004, hal 51-60. (online) www.jurnal baca tulis permulaan. Diakses 22 Juli 2018.

Stockard, J. (2010). Improving Elementary Level Mathematics Achievement in a Large Urban District: The Effects of Direct Instruction in the Baltimore City Public 
School System. Journal of Direct Instruction, 10: 1-16.

Susilo, Sigit Vebrianto. Metode Pembelajaran Pengetahuan Awal terhadap Kemampuan Membaca Permulaan Siswa. Jurnal Pendidikan Dasar (Kajian Teori dan Hasil Penelitian). Vol. 7, nomor: 1, 2016, p-ISSN 2086-7433, eISSN 2549-5801, hal. 150-167. (online). Diakses 3 Agustus 2018.

Syah, Muhidin. Psikologi Pembelajaran. Jakarta: Gramedia Pustaka Utama, 2014.

Taufina. 2017. Sumber Belajar Penunjang PLPG Kompetensi Profesional Mata Pelajaran: Guru Kelas SD Unit I: Bahasa Indonesia. Jakarta: Kementerian Pendidikan dan Kebudayaan Direktorat Jenderal Guru dan Tenaga Kependidikan.

Ulum, Muhammad Miftahul. Peningkatan Prestasi Membaca Permulaan Anak Berkesulitan Belajar Membaca Menggunakan Model Pembelajaran Kontekstual melalui Inklusi di SDN Pajang 1 Surakarta. Proseding Seminar Nasional Pendidikan Surakarta. 225229.

Wood, Janice and McLemore, Bronwyn. 2001. Critical Components in Early Literacy - Knowledge of the Letters of the Alphabet and Phonics Instruction. The Florida Reading Quarterly. 38(2): 1-8 